\section{Desertification: another mirage?}

\author{
Robin Sharp reports on the UN Conference \\ which ended in Nairobi earlier this month
}

$\mathrm{D}^{\mathrm{E}}$ ESERT rash is an ugly dermatitis which spreads in blotches and peels off bits of the world's skin. Having diagnosed it, traced it to no fewer than 45 sources and called it desertification, the United Nations has this month successfully patented a selection of medicines to control and cure the disease.

The UN Conference on Desertification (UNCOD) was very much a synthetic event, in the best sense of the term. Neither a scientific nor essentially a political gathering, it sought to bring together a range of disciplines and socio-political interests to create a new holistic approach to the problems of desert rash in the world's dry lands. The conference did not pretend to be inventing a new branch of science but rather a new conceptual framework for research and policy-making. Judging by the high degree of consensus among the 90 countries present on the ailment and its cure, this seems to have been achieved.

One danger with a newly-identified problem is that people too readily assume it needs new-fangled solutions. In the case of desertification, the teams of experts who produced the basic conference documents were cautious enough to recognise modern technology as one of the hazards as well as the hopes. Because of their fragility, the principal document noted, dryland ecosystems are particularly vulnerable to misapplied technology; and in the developing countries where acceptance by the local community is a critical factor, modifications of existing technology and practice are more likely to be effective than radical innovation.

In their official conference paper, 'Ecological change and desertification', Andrew Warren and Judith Maizels of University College, London, also warn that stories of technological success in dryland agriculture "should not be accepted complaisantly". Fifteen million hectares of land have been irrigated along the Indus River in Pakistan, for example, but an estimated two-thirds of this vast area is now affected by consequent waterlogging and salinisation.

The conference was presented with three other 'component reviews' covering technology, climate and human and social factors. All four were then summarised in an overview report, which

Robin Sharp is a freelance consultant and writer on development affairs provided the basis for the first part of the conference debate. In fact, apart from various nuances and some disagreement over whether and how to define the neologism coined for the conference title, there was little dispute over the secretariat's analysis of the causes and effects of desertification.

\section{Bone of contention}

The only real bone of contention was whether or not, as averred by $\mathrm{Dr}$ Mostafa Tolba, the conference Secretary-General, "man now has in his possession both the wealth of knowledge and adequate technical means to bring desertification to a halt and, in many instances, to reverse the process". The overview paper emphasised the same point, asserting that the knowledge and experience to tackle most aspects of the problem was "available right now".

This, however, was not good enough for the six national and regional science associations which held a seminar in Nairobi immediately before the conference to feed in their views. In their opinion it reflected an implicit over confidence in the adequacy of existing technology, not to mention an underestimation of the human and economic costs which in the short-term could well rival the costs of the problem itself.

Both concerns drew attention in the debate, a number of countries pointing out that more basic and applied research was still needed in areas such as water harvesting, rainfall prediction, water desalination, alternative energy sources and water-crop relationships. Several delegates stressed the need for intensified efforts in the field of climatology and a closer working relationship between climatologists and agriculturalists at various levels.

One experiment which may eventually enable climatological events to be predicted in the world's dry regions is to be launched next year by the World Meteorological Organisation (WMO). Under its Global Atmospheric Research Programme (GARP), run jointly with the International Council of Scientific Unions, the WMO will make detailed worldwide observations of the atmosphere over a 12-month period. It is described as the largest scientific experiment ever undertaken internationally for peaceful purposes, using satellites, aircraft, ships, balloons and Press handouts, so they'd better come up with something.

\section{Plan of action}

After agreeing that desertification has many causes and that most are man-made, the conference then moved on to consider what could be done about them. Though most of it may be no more than a set of guidelines for any government caring to take note, the UN conference formula these days makes it de rigueur to produce a 'plan of action'. And as these things go, the desertification action plan went pretty well. It recommended careful assessment and monitoring of the extent of desertification, proper management of water resources, rangelands, livestock and wildlife, urgent measures to overcome the lost of water and land caused by irrigation, special steps to improve soil conservation, national land-use planning, and-just to make sure that nothing was left out--"national systems for monitoring the human condition".

Focusing on the developing countries, the 'plan of action' called for measures to strengthen indigenous capabilities in science and technology, paying special attention to the rational use of dryland resources. This might include setting up or strengthening national scientific institutions concerned with desertification. The plan further urged that research be vigorously pursued on cheap alternative energy sources which could help to halt the alarming rate of deforestation caused by the pressure of demand for firewood in many dry countries.

Pilot project experiments could be set up to test the use of wind energy for generators and water pumps, and solar energy for water heaters and distillers, cookers, food dryers and refrigerators. On all these points the conference anticipated further action at the second UN Conference on Science and Tecnology to be held in two years' time.

The need for public awareness campaigns to educate people in general and dryland populations in particular about the sustainable use of their environment was emphasised by a number of countries. As the Australian delegation put it, the people contributing to the problem must be made aware of its existence and causes. On another tack, the Australians were scathing about the special desertification map produced for the conference. Not only did it contain serious errors, but at a scale of $1: 25,000,000$ it wasn't going to be much help and in any case the validity of mapping a set of dynamic processes was questionable.

\section{Less than enthusiastic}

For similar reasons, they were less than enthusiastic about the use of information from remote-sensing satellites as an anti-desertification tech- 
nique. Out of six transnational feasibility studies drawn up for the conference, two were devoted to the monitoring of desertification in southwest Asia and South America by Landsat imagery, using the Earth Resources Technology Satellite (ERTS). The use of satellite imagery thus came in for quite a bit of notice, but the Austrailans and others thought it had aroused "excessive expectations" and reckoned that for most purposes 'ground truth' observations were a much better bet.

The transnational feasibility studies were commissioned as the basis for possible inter-governmental agreements on large-scale regional projects to combat desertification. Apart from the two remote-sensing schemes, the studies provide for the planting of 'green belts' north and south of the Sahara, the management of livestock and rangelands in seven countries of the SudanSahelian region, and management of the major regional aquifiers in northeast Africa and the Arabian Peninsula. Though challenged on grounds both of cost and effectiveness, the Secretariat was able to claim that several governments had already significd their readiness to go ahead.

Inevitably in the volume of research amassed for this meeting there were a number of inconsistencies, plus a few worrying omissions. At some points in the documents and the debate, the need of developing countries for simple, low-cost technologies was carefully stressed, but elsewhere sophisticated remedies were advanced without much evidence whether those to whom they were addressed could or should afford them. Likewise, it was acknowledged that desirable changes in traditional farming and other forms of land use were subject to important economic, social and cultural restraints. Yet when it came to calculating how readily the threatened drylands would respond to the conference's action package, the implications of this seem to have been overlooked in favour of more measurable financial, scientific and administrative criteria.

\section{Two omissions}

Two significant factors in the desertification process were glossed over in Nairobi, intentionally or otherwise. Firstly, though the UN Food and Agriculture Organisation (FAO) has a conference on land reform scheduled for next year, the degree to which feudal or other land tenure systems still contribute to desertification in several countries-for example erosion caused by peasants forced out of the valleys to farm marginal slopes-was studiously ignored. And again, no one asked aloud whether those governments determined to get their nomads settled

\section{Marginal living on the Saharan fringe}

down had analysed the long-term consequences of demobilising the people best equipped to balance the economic potential and the limitations of life on the desert margin.

Pehaps the secretariat was a bit too anxious not to rumle any political feathers. In any event, for better or worse, this was one of the least politicised UN meetings in recent times. Apart from an Arab move obliging the conference to pretend that Israel's impressive record of desert reclamation did not exist, the proceedings were remarkably free of ideological entanglements.

Of course there had to be a bit of a crunch at the end, and, not surprisingly, it centred on cash and administrative machinery for the postconference follow-through. True to form, the industrialised countries came out against the creation of any new international body for desertification which they might have to pay for. They were having nothing to do with the notion of an international tax to help finance the 'plan of action', and Dr Tolba knew the odds when he conceded at the start that there might be "some problems" in attempting to set up another Special Fund for the purpose.

In the end, as everyone expected, the follow-through responsibility was handed over from Dr Tolba, SecretaryGeneral of the conference, to Dr Tolba, Executive Director of the UN Environment Programme. For whatever apprehensions there might be in various capitals about UNEP, it was the cheapest, neatest, most logical answerand Dr Tolba was generally acknowledged to have done a masterly job in getting the show on the road.

So from its barrack-like HQ on the outskirts of Nairobi, enlivened with outdoor murals of wallowing hippos and the like, UNEP will now have the task of pulling all the other UN agencies together to work out uniform methodologies, to coordinate and expand their research efforts on desertification and to build a solid organisational structure inside the conference's conceptual scaffolding. A mammoth task, one might say, but there's no doubt much has been accomplished in the two years leading up to the conference.

\section{Not too disappointing}

By the time UNDP, UNIDO, FAO, UNESCO, WMO, WHO, the World Bank and others have reshuffled their budget headings to make room for this new arrival, even the present level of spending to combat desertification will probably not look too disappointing, given the many competing development priorities. And it should be worth much more if and when all the bits are linked into a concerted programme. Added to this, according to one estimate, are 15,000 or more researchers and 300 institutions around the world already involved in arid-land research.

With resources on this scale available to be mustered in a global campaign, the prospect of halting and pushing back the deserts might appear no longer a mirage. But there's still one more snag the conference tended to forget. By the year 2000, when the 'plan of action' is due to be fully implemented, the population of the world's drylands, now around 600 million, will be up to 1,000 million or more, with all the concomitant pressures this will bring. Those charged with the problem may therefore find themselves having to run very hard just to stand still. And come to think of it, that is a bit like chasing a mirage, after all. 